\title{
PENGARUH BUDAYA ORGANISASI DAN KOMPENSASI TERHADAP KINERJA GURU DISMK NEGERI SE-KOTA PEKANBARU
}

\author{
Faizal 1) \\ Makhdalena 2) \\ Rr. Sri Kartikowati ${ }^{3)}$ \\ 1) Post Graduate Student of Riau University \\ 2) Lecturer of Education Management Study Programme PPs University of Riau \\ ${ }^{3)}$ Lecturer of Education Management Study Programme PPs University of Riau
}

\begin{abstract}
This study aims to determine the influence of organizational culture and compensation both simultaneously and partially affect the performance of teachers, and to figure out how big the influence of organizational culture and compensation both simultaneously and partially affect the performance of teachers at in SMK Negeri across Kota Pekanbaru. The method used in this research is quantitative descriptive method, which is to obtain a description of the actual condition that exists in place of research and proving hypothesis concerning the relation of research variables: organizational culture, compensation, and teacher performance. The population of this study were civil servant teachers at SMK Negeri in Pekanbaru City which amounted to 397 people, while the sample was 80 people. The results of this study based on multiple regression analysis showed that, simultaneously organizational culture and compensation affects the performance of teachers, amounting to $57.3 \%$. while partially organizational culture influence on teacher performance, equal to $5.00 \%$ and partially shows compensation effect on teacher performance of 5.32\%; Based on the above description can be concluded, that organizational culture and compensation have a positive and significant impact on teacher performance either simultaneously or partially.
\end{abstract}

Keywords: Organizational Culture, Compensation, Teachers Performance 


\title{
PENGARUH BUDAYA ORGANISASI DAN KOMPENSASI TERHADAP KINERJA GURU DISMK NEGERI SE-KOTA PEKANBARU
}

\begin{abstract}
ABSTRAK
Penelitian ini bertujuan, untuk mengetahui pengaruh budaya organisasi dan kompensasi baik secara simultan maupun secara parsial berpengaruh terhadap kinerja guru di SMK Negeri se-kota Pekanbaru, dan untuk mengetahui seberapa besar pengaruh budaya organisasi dan kompensasi baik secara simultan maupun secara parsial berpengaruh terhadap kinerja guru di SMK Negeri Sekota Pekanbaru.

Metode yang dipakai dalam penelitian ini adalah metode deskriptif kuantitatif, yaitu untuk memperoleh gambaran mengenai kondisi yang sebenarnya yang ada di tempat penelitian dan pembuktian hipotesis mengenai keterkaitan variabel penelitian: budaya organisasi, kompensasi, dan kinerja guru.

Populasi penelitian ini guru PNS di SMK Negeri se-Kota Pekanbaru yang berjumlah 397 orang, sedangkan sampel sebanyak 80 orang. Hasil penelitian ini berdasarkan analisa regresi berganda menunjukan bahwa, secara simultan budaya organisasi dan kompensasi berpengaruh terhadap kinerja guru, sebesar 57,3\%. sementara secara parsial budaya organisasi berpengaruh terhadap Kinerja guru, sebesar 5,00\% dan secara parsial menunjukkan Kompensasi berpengaruh terhadap kinerja guru sebesar 5,32\%; Berdasarkan uraian di atas dapat disimpulkan, bahwa budaya organisasi dan kompensasi berpengaruh positif dan signifikan terhadap Kinerja guru baik secara simultan maupun secara parsial.
\end{abstract}

Kata Kunci: Budaya Organisas;, Kompensasi; Kinerja Guru

\section{PENDAHULUAN}

Pembukaan Undang-Undang Dasar 1945 pada alinea keempat bahwa tujuan Negara Indonesia adalah melindungi segenap bangsa Indonesia dan seluruh tumpah darah Indonesia dan untuk memajukan kesejahteraan umum, mencerdaskan kehidupan bangsa dan ikut melaksanakan ketertiban dunia yang berdasarkan kemerdekaan, perdamaian abadi dan keadilan sosial, maka disusunlah Kemerdekaan Kebangsaan Indonesia. Untuk mewujudkan tujuan nasional tersebut, pendidikan merupakan salah satu faktor menentukan namun sampai saat sekarang mutu pendidikan masih rendah dan belum berhasil.

Amanat Undang-Undang Dasar

Negara Republik Indonesia 1945 tersebut diatur lebih lanjut UndangUndang Republik Indonesia No. 20 tahun 2003 tentang sistem Pendidikan Nasional. Pendidikan adalah usaha sadar dan terencana untuk mewujudkan suasana belajar dan proses pembelajaran agar peserta didik secara aktif mengembangkan potensi dirinya untuk memiliki kekuatan spiritual keagamaan, pengendalian diri, kepribadian, kecerdasan, akhlak mulia, serta keterampilan yang diperlukan dirinya, masyarakat, bangsa dan negara.

Mewujudkan tujuan pendidikan nasional membutuhkan guru yang berkualitas dan profesionalisme. Guru merupakan kunci utama atau ujung tombak untuk merealisasikan tujuan pendidikan nasional, dalam suatu sekolah. Sekolah yang bermutu tentu diisi oleh guru-guru yang berkualitas. 
Guru berkualitas tentu akan menghasilakan output, dan outcomes yang baik dan berguna bagi masyarakat. Untuk menjadi guru harus mempunyai kompetensi, yaitu: Kompetensi profesionalisme, kompetensi pedagogis, kompetensi kepribadian, dan kompetensi sosial. Guru yang memiliki 4 kompentensi tersebut akan mampu menjalankan tugas utamannya dan melahirkan siswa bermutu bagi masyarakat, bangsa dan Negara.

Menurut Undang-Undang Republik Indonesia No. 14 Tahun 2005 tentang Guru dan Dosen tugas utama seorang guru ialah mendidik, mangajar, membimbing, mengarahkan, melatih, minilai, dan mengevaluasi perserta didik. Guru tidak hanya memberi pengetahuan tetapi menjadi seorang guru harus mampu membentuk karakter perserta didik dan guru merupakan contoh teladan bagi perserta didik dalam segala tindakan dan perbuatan yang dilakukan. Baiknya seseorang perserta didik tentu mempunyai guru yang berkualitas, mempunyai kompetensi dan kinerja yang baik.

Menurut Chaterina Melina Taurisa, dan Intan Ratnawati (2012: 172) Kinerja merupakan hasil kerja secara kualitas maupun kuantitas yang dicapai oleh seseorang dalam melaksanakan tugas yang diberikan kepadanya sesuai dengan standar atau kriteria yang telah ditetapkan.

Sekolah Menengah Kejuruan didirikan bertujuan menyiapkan siswa yang siap berkerja di dunia industri maupun dunia usaha, siap membuka lapangan pekerjaan atau menjadi wirausahawan dan melanjutkan perguruan tinggi. Sekolah Menengah Kejuruan diharapkan mampu menghasilkan lulusan yang berkualitas dan bisa diterima oleh dunia industry, dunia usaha, perguruan tinggi dan masyarakat umum. Untuk mewujud hal tersebut membutuhkan guru yang mempunyai kompetensi, professional dan dapat bertanggung jawab atas tugas dan kewajibannya, sehingga menghasilkan siswa berkualitas, dan bisa membimbing siswa supaya berprestasi. Terlihat dilapang kinerja guru di Sekolah Menengah Kejuruan Negeri Sekota Pekanbaru masih belum optimal dalam mengajar.

Dari hasil observasi dan wawancara dengan kepala sekolah, peneliti melihat permasalahan kinerja yang perlu diteliti lebih lanjut hingga menghasilkan sebuah perubahan. Di antaranya, guru masih ada yang belum maksimal menyusun perencanaan pembelajaran. Hasil wawancara peneliti dengan kepala sekolah, penulis menemukan ada sekitar $30 \%$ guru belum maksimal dalam membuat perencanaan pembelajaran sebelum awal semester. Kemudian guru dalam membina hubungan sosial antara sesama guru, guru dengan siswa, dan guru dengan orang tua siswa, belum terjalin dengan baik. Dari hasil observasi peneliti di lingkungan sekolah, peneliti menemukan sekitar $20 \%$ guru tidak adanya tegur sapa antara guru dan siswa ketika berada di lingkungan sekolah. selanjutnya belum objektif penilaian guru terhadap hasil belajar siswa. Hal ini terlihat dari hasil wawancara peneliti dengan kepala sekolah ada sikitar 50\% guru belum menilai secara objektif atas sikap dan kemampuan siswa. Beberapa fenomena diatas dapat terlihat bahwa belum maksimalnya kinerja guru, dalam menjalankan tugas dan tanggungjawab.

Dari permasalahan tersebut supaya mendapatkan kinerja yang maksimal, guru dan karyawan membutuhkan adanya budaya organisasi yang baik di sebuah sekolah. Menurut Robbins dan Judge dalam jurnal Chaterina Melina dan Intan Ratnawati (2012: 173) Budaya organisasi sebagai suatu sistem 
makna bersama yang dianut oleh anggota yang membedakan organisasi tersebut dengan organisasi lain. Hasil penelitian Mishan (2014: 12) Budaya organisasi mempunyai pengaruh yang signifikan terhadap kinerja guru. Maknanya bahwa semakin tinggi nilai budaya organisasi, maka kinerja guru semakin baik. Sebaliknya semakin rendah nilai budaya organisasi, maka semakin rendah pula kinerja guru. Budaya organisasi juga dapat diartikan sebagai pola yang terpadu dalam perilaku pegawai pada suatu organisasi, termasuk pula pemikiran-pemikiran, tindakan-tindakan, pembicaraanpembicaraan yang dipelajari dan diajarkan kepada generasi berikutnya.

Selain faktor budaya organisasi, kinerja pegawai juga dipengaruhi oleh adanya kompensasi. Menurut Admosudiro (2012: 23) mengemukakan kompensasi balas jasa adalah penghargaan kepada pegawai secara adil dan layak untuk hasil kerja dan atas jasa yang telah dikeluarkan terhadap tujuan organisasi. Balasan yang diberikan dapat saja setimpal, akan tetapi dapat saja diberikan tidak setimpal atau tidak sebanding. Namun idealnya balas jasa tersebut diberikan secara sebanding dan setimpal. Hasil penelitian Dedy Kusumah Wijaya dan Anik Herminingsih bahwa kompensasi memiliki pengaruh terhadap kinerja guru. Hal ini didukung oleh data yang menyatakan bahwa hasil kerja baik tentu didukung oleh gaji pokok, tunjang, dan penghargaan yang diberikan maksimal.

Dapat penulis simpulkan dari beberapa fenomena-fenomena diatas penulis mengambil judul tesis" Pengaruh Budaya Organisasi dan Kompensasi terhadap Kinerja Guru SMK Negeri Sekota Pekanbaru". Dengan penelitian ini bisa memberikan solusi-solusi bagi permasalahn belum optimalnya Kinerja Guru SMK Negeri Sekota Pekanbaru.

Tujuan utama melakukan kegiatan penelitian ini adalah untuk menganalisis sebagai berikut: 1). Untuk mengetahui budaya organisasi dan kompensasi baik secara simultan maupun secara parsial berpengaruh terhadap kinerja guru di SMK Negeri Sekota Pekanbaru. 2). Untuk mengetahui Seberapa besar pengaruh budaya organisasi dan kompensasi baik secara simultan maupun secara parsial berpengaruh terhadap kinerja guru di Sekolah Menengah Kejuruan Negeri Sekota Pekanbaru.

\section{TINJAUAN PUSTAKA}

\section{Kinerja Guru}

Kinerja merupakan hasil kerja secara kualitas maupun kuantitas yang dicapai oleh seseorang dalam melaksanakan tugas yang diberikan kepadanya sesuai dengan standar atau kriteria yang telah ditetapkan. Produktifitas tentu di pengaruhi oleh tingginya kinerja, dan apa bila produktifitas turun tentu di pengaruhi oleh rendahnya kinerja seorang guru. Ruky dalam buku Supardi (2014: 45) dilihat dari kata kinerja berasal dari kata Performance. Kata "performance" mempunyai tiga arti yaitu: pertama prestasi, kedua petunjuk, dan ketiga pelaksanaan tugas. Dari pengertian diatas kinerja diartikan sebagai prestasi guru dalam melaksana tugas sesuai dengan kemapuan dan tanggungjawab yang diberikan oleh pemerintah dan sekolah. Maka didukung oleh Pendapat Mangkunegara dalam Jurnal Sunarno dan Lie Liana (2001: 6) kinerja dapat didefinfisikan sebagai hasil kerja secara kualitas dan kuantitas yang dapat dicapai oleh seseorang karyawan dalam melaksanakan tugas sesuai dengan 
tanggung jawab yang diberikan kepadanya. Sesuai tugas yang di berikan oleh sekolah kepada guru berdampak pada kualitas dan kuantitas suatu pekerjaan yang di hasilkan demi kemajuan lembaga. Sedangkan Menurut Irham Fahmi (2011: 126) Kinerja adalah hasil yang diperoleh oleh suatu organisasi baik organisasi bersifat profit oriented dan non profit oriented yang dihasilkan selama satu periode. Menurut Jason A. Colquitt, dkk. (2004: 37) Job Performance is formally defined as the value of the set of employee behaviors that contribute, either positively or negatively, to organizational goal accomplishment. Sedangkan pengertian guru Undang-Undang Republik Indonesia No. 14 Tahun 2015 tentang Guru dan Dosen; Guru merupakan pendidik professional dengan tugas utama mendidik, mengajar, membimbing, mengarahkan, melatih, menilai dan mengevaluasi pada usia dini, pendidikan dasar, dan pendidikan menengah. Guru wajib memiliki empat kompetensi yaitu: Kompetensi professional, kompetensi sosial, kompetensi pedagogis, dan kompetensi kepribadian. Jika guru menguasai empat kompetensi tersebut akan mampu menjalankan tugas sebagai pendidik, mengajar, mengevaluasi, dan melatih para perserta didik. Guru merupakan penentu keberhasilan pendidikan melalui kinerja yang baik. Menurut Silverius dalam jurnal Mishan (2014: 5) guru adalah tokoh sentral dalam pendidikan untuk menyiapkan kader bangsa di masa depan, kunci sukses reformasi pendidikan. Beberapa faktor yang mempengaruhi proses dan hasil belajar siswa, faktor guru mendapat perhatian yang pertama dan utama, karena baik- buruknya pelaksanaan kurikulum pendidikan pada akhirnya bergantung pada aktivitas dan kreativitas guru dalam menjabarkan dan merealisasikan kurikulum tersebut. Berdasarkan Peraturan Manteri Pendidikan Nasional No. 35 Tahun 2010 menjelaskan Kinerja guru adalah hasil penilaian terhadap proses dan hasil kerja yang dicapai guru dalam melaksanakan tugasnya. Menurut Supardi (2014: 54) Kinerja Guru Merupakan kemampuan seseorang guru dalam melaksanakan tugas pembelajaran di sekolah/madrasah dan bertanggungjawab atas perserta didik di bawah bimbinganya dengan meningkatnya prestasi belajar perserta didik. Jadi, dapat sentesakan oleh penulis bahwa kinerja guru adalah suatu hasil kerja dalam melaksanakan, mengerjakan, dan tanggungjawab atas tugas pembelajaran di sekolah agar meningkat prestasi siswa, dan tercapainya tujuan pendidikan. artinya kinerja guru yang berkualitas dalam menjalankan tugas utamanya yaitu: mendidik, mengajar, membimbing, mengarahkan, penilaian, dan evaluasi perserta didik, maka akan menghasilkan perserta didik yang berprestasi sesuai bidang keahliannya, maka akan tercapainya tujuan pendidikan nasional.

Menurut Sanjaya dalam jurnal Mishan (2014: 6) bahwa indicator kinerja guru sebagai berikut: perencanaan pembelajaran, pengelolaan pembelajaran, pelaksanaan penilaian hasil pembelajar, pelaksanaan program perbaikan dan pengayaan terhadap siswa. Sedangkan menurut Supardi (2014: 49) indikator kinerja guru adalah pengetahuan, keterampilan, sistem penempatan, dan unit variasi pengalaman, kemampuan praktis, kualifikasi, hasil, pekerjaan, dan pengembangan. Selanjutnya menurut Supardi (2014: 73) indikator kinerja guru adalah kemampuan menyusun rencana pembelajaran, kemampuan melaksankan pembalajaran, kemampuan mengadakan hubungan 
antar pribadi, kemampuan menilia hasil belajar, kemampuan melaksanakan pengayaan, dan kemampuan melaksanakan remedial. Dari uraian dan deskripsi mengenai indikator kinerja guru dapat dibuat sintesa teori yang dimaksud dengan kinerja guru adalah, Kemampuan menyusun perencanaan pembelajaran, kemampuan melaksanakan pembelajaran, mengadakan hubungan antara pribadi, kemampuan menilai hasil belajar, mengadakan remedial, dan pengayaan pembelajaran.

Menurut Supardi (2014: 50) ada dua faktor yang mempengaruhi kinerja guru ada faktor internal dan faktor eksternal. Faktor internal yang mempengaruhi kinerja guru adalah faktor yang datang dalam diri individu yaitu; kemampuan, keterampilan, mental, fisik, kepribadian, sikap, dan persepsi, sedangkan faktor eksternal yang mempengaruhi kinerja guru adalah faktor yang datang dari organisasi yaitu ;kepemimpinan, perilaku manajemen, desain jabatan, imbalan, sumber daya, dan struktur organisasi. Menurut Sedarmayanti (2014: 19) menjelaskan kinerja guru dipengaruhi beberapa faktor-faktor atara lain: sikap mental (motivasi kerja, disiplin kerja, etika kerja), pendidikan, keterampilan, manajemen kepemimpinan, tingkat penghasilan, gaji dan kesehatan, jaminan sosial, iklim kerja, sarana prasarana, teknologi, kesempatan berprestasi. Menurut Pasolong (2008: 75) ada delapan faktor yang mempengaruhi kinerja dalam sebuah organisasi yaitu: Kompentensi, kemauan, energy, teknologi, kepemimpinan, kompensasi, kejelasan tujuan, dan keamanan. Sedangkan menurut Torrington dan Hall dalam buku Syamsir Torang (2014: 75) ada enam yang mempengaruhi kinerja komitmen, tanggungjawab dan fasilitas, kepemimpinan, budaya, keeratan hubungan antara individu dalam organisasi, proses pembelajaran sebagai cara dalam meningkatkan kapabilitas individu. Dengan demikian, dapat diartikan bahwa yang dapat mempengaruhi kinerja guru adalah faktor intern yaitu: fisik, kecerdasan, keterampilan, mental, motivasi, bakat sedangkan faktor ekstern budaya sekolah, lingkungan kerja sekolah, komunikasi, kompensasi, sarana dan prasarana, kepemimpinan dan budaya.

\section{Budaya Organisasi}

Budaya organisasi sering muncul dan bahkan menjadi bahan pembicaraan para ilmuan. Hal ini menunjukkan bahwa organisasi itu dirasakan penting dan memiliki manfaat langsung maupun tidak langsung terhadap perkembangan organisasi. Budaya organisasi terdiri dari dua kata yakni budaya dan organisasi. Kata budaya menurut Forehand and von Gilmer (1964: 997) Culture is arrangement of different attributes that express an organization and differentiate the firm from other one. Budaya merupakan penataan aturan, kebiasaan, dan nilai-nilai yang diekpresikan dalam organisasi, dan salah satu yang membedakan organisasi lain. Sedangkan menurut James D. Mooney dalam buku Sutarto (2006: 20) organization is the form of every human association for the attainment of common purpose. Sebuah asosiasi manusia berinteraksi untuk mencapai tujuan yang telah ditetapkan oleh organisasi. Untuk mencapai tujuan organisasi di butuhkan aturan, nilainilai, asumsi, kebiasaan yang dilakukan suatu organisasi atau sekolah. Namun didukung pendapat McShane \& Von Glinow (2008: 460) menjelaskan "organization's culture consists of the values and assumptions shared within an organization. Membatasi budaya 
organisasi sebagai pola asumsi dasar dan nilai-nilai dimiliki bersama dalam sebuah organisasi atau sekolah. Jason A. Colquitt, dkk (2004: 546-547) Organizational culture as the shared social knowledge within an Organizational regarding the rules, norms, and values that shape the attitudes and behaviors of its employees. Sedangkan menurut Stoner dalam jurnal Abdul Hakim \& Anwar Hadipapo (2015: 3) budaya (culture) merupakan gabungan kompleks dari asumsi, tingkah laku, cerita, mitos, metafora dan berbagai ide lain yang menjadi satu untuk menentukan apa arti menjadi anggota masyarakat tertentu. Selanjutnya menurut Robbin dalam jurnal Abdul Hakim \& Anwar Hadipapo (2015: 1) budaya organisasi adalah suatu sistem makna bersama yang dianut oleh anggota-anggota yang membedakan organisasi itu dari organisasi-organisasi lain. Sedangka menurut Mulyasa (2015: 102) budaya sekolah merupakan salah satu kebijakan yang harus diperhatikan kementerian pendidikan dan kebudayaan dalam rangka peningkatan mutu pendidikan budaya sekolah yang kondusif diharapkan dapat menunjang proses pembelajaran yang efektif, sehingga semua pihak terlibat didalamnya, khususnya perserta didik merasa nyaman belajar. Jadi dapat disintesakan budaya organisasi merupakan suatu sistem makna bersama yang dipegang oleh anggota, baik berupa nilai, normanorma, dan kebiasaan yang digunakan untuk memecahkan masalah, dan membedakan dengan organisasi lain.

Stephen P. Robbins dalam buku Wibowo (2016: 33) mengemukakan adanya tujuh indikator budaya organisasi sebagai berikut:

1. Innovation and risk taking (inovasi dan pengambilan resiko), suatu tingkatan dimana pekerja didorong untuk menjadi inovatif dan mengambilkan resiko.

2. Attention to detail (perhatian pada hal yang detail), dimana pekerja diharapkan menunjukkan ketepatan, analisis, dan perhatian pada hal detail.

3. Outcome orientation (orentasi pada manfaat), di mana manajemen focus pada hasil atau manfaat dari pada sekedar pada teknik dan proses yang dipergunakan untuk mendapatkan manfaat tersebut.

4. People orientation (orientasi pada orang), dimana keputusan manajemen mempertimbangkan pengaruh manfaatnya pada orang dalam organisasi.

5. Team Orientation (orientasi pada tim), di mana aktifitas kerja diorganisasi berdasarkan tim dari pada individual.

6. Aggressiveness (agresivitas), di mana orang cenderung lebih agresif dan kompetitif dari pada easygoing .

7. Stability (stabilitas), di mana aktivitas organisasional menekankan pada menjaga status quo sebagai lawan dari perkembangan.

Menurut Greenberg dan Robert A. Baron dalam buku Wibowo (2016: 3233) mengemukakan tujuh indikator budaya organisasi sebagai berikut:

1. Innovation (Inovasi), suatu tingkatan di mana orang diharapkan kreatif dan membangkitkan gagasan baru.

2. Stability (Stabilitas), bersifat menghargai lingkungan yang stabil, dapat diperkirakan, dan berorentasi pada peraturan.

3. Orientation toward people (orientasi pada orang), merupakan orientasi untuk menjadi jujur, mendukung, dan menunjukkan penghargaan pada hak individual. 
4. Result orientation (orientasi pada hasil), meletakkan kekuatannya pada kepeduliannya untuk mencapai hasil yag diharapkan.

5. Easygoingness (bersikap tenang), suatu keadaan di mana tercipta iklim kerja bersifat santai.

6. Attention to detail (perhatian pada hal detail), dimaksudkan dengan berkepentingan untuk menjadi analitis dan seksama.

7. Collaborative orientation (orientasi pada kolaborasi), merupakan orientasi yang menekankan pada bekerja dalam tim sebagai lawan dari bekerja secara individual.

Dapat disentesa ada tujuh indikator budaya organisasi yaitu: inovasi dan pengambilan resiko, perhatian pada hal detail, orientasi pada hasil, orientasi pada orang, orientasi pada tim, agresivitas, stabilitas.

\section{Kompensasi}

Pembahasan dalam pemberian kompensasi kepada guru harus patut menjadi perhatian pemerintah maupun sekolah, maka konsep pemberian kompensasi akan di jelaskan para ahli di bidangnya. Menurut Werther and Davis dalam Buku M. Kadarisman (2012: 1) compensation is what employes recieve in exchange of the work, whether hourly wages or periodic salaries, the personnel department usually designs and administers employee compensation. Berdasarkan pemikiran dalam pengertian kompensasi bagi tenaga pendidik dan kependidikan merupakan balas jasa atas pekerjaan baik berupa upah per jam atau gaji periodic yang didesain oleh pemerintah dan sekolah. Kompensasi yang diberikan kepada tenaga pendidik dan kependidikan bisa berbentuk uang bisa dalam bentuk tidak uang. Sedangkan kompensasi Menurut Holt (1993: 302) Compensation is output and the benefit that employee receive in the form of pay, wages and also same rewards like monetary exchange for the employee's to increases the Performance. Konsep yang di jelaskan oleh Holt kompensasi merupakan keutungan yang diterima oleh tenga pendidik dan kependidikan dalam bentuk gaji, upah dan imbalan dalam bentuk tidak uang untuk meningkatkan kinerja. Kinerja baik tentu imbalan yang diterima setimpal apa yang didapatkan oleh tenga pendidik dan kependidikan dalam melaksanakan pekerjaan. Sedangkan pengertian kompensasi Menurut Priyono \& Marnis (2008: 223) Kompensasi merupakan semua pendapatan yang berbentuk uang atau barang langsung atau tidak langsung yang diterima guru sebagai imbalan atas jasa yang diberikan kepada Sekolah. Sebagai penghargaan sekolah terhadap tenga pendidik dan kependidikan dari hasil kerja guru kepada dunia pendidikan, maka pemerintah dan sekolah memberikan balas jasa, imbalan jasa, penghargaan, penghasilan atau reward. Kemudian di perkuat oleh Undang-Undang Republik Indonesia Nomor 14 Tahun 2005 tentang Guru dan Dosen menjelaskan gaji atau kompensasi adalah hak yang diterima oleh guru atau dosen atas pekerjaannya dari penyeanggara pendidikan atau satuan pendidikan dalam bentuk financial secara berkala sesuai dengan peraturan perudang-undangan. Sedangkan Menurut Veithal Rivai (2004: 357) Kompensasi merupakan sesuatu yang diterima karyawan sebagai pengganti konstribusi jasa mereka pada sekolah. Kompensasi yang diterima oleh tenga pendidik dan kependidikan merupakan kontribusi diberikan kepada sekolah. Kompensai financial terbagi beberapa komponen, kompensasi langsung terdiri dari pembayaran tenga pendidik dan kependidikan dalam 
bentuk upah, gaji, bonus, atau komisi. Sedangkan kompensasi tidak langsung terdiri dari liburan, asuransi, jasa seperti perawatan anak atau kepedulian keagamaan, dan sebagainya. penghargaan financial nonfinasial seperti pijian, menghagai diri sendiri, pengakuan yang diberikan kepada guru akan meningkatkan kinerja. Maka dapat disentesakan kompensasi merupakan imbalan yang diberikan kepada guru atas pekerjaan yang dilakukan, baik imbalan financial langsung, tidak langsung, dan non finalsial sesuai ketetapan pemerintah atau sekolah.

Sedangkan menurut Veithzal dalam jurnal Aan Hardiyanan, dkk (2013:68) indikator kompensasi adalah langsung, dan tidak langsung. Sedangkan menurut Veithzal Rivai (2005: 360-362) gaji, upah, insentif, kompensasi tidak langsung. Selanjutnya indikatorindikator kompensasi menurut Simamora dalam jurnal Tanto Wijaya dan Fransisca Andreani (2004: 40) diantaranya : upah dan gaji, insentif, tunjangan, dan fasilitas. Menurut Nurul Ulfatin dan Teguh Triwiyanto (2016:123-124) indikator kompensasi adalah gaji dan upah, insentif, tunjangan, jaminan kesehatan dan kesejahtraan, kompensasi karier, dan kompensasi sosial. Dapat disentesa indikator kompensasi adalah gaji, tunjangan, jaminan kesehatan, kompensasi karier, kompensasi sosial, fasilitas, insentif. Semua indikator ini menjadi patokan mengukur seberapa besar kompensasi yang didapat oleh guru baik kompensasi tidak langsung maupun kompensasi langsung.

\section{KERANGKA PEMIKIRAN}

Budaya organisasi dan kompensasi berpengaruh posifit dan signifikan baik secara parsial dan simultan terhadap kinerja guru di sekolah. Adanya budaya organisasi yang baik akan berpengaruh terhadap kinerja guru, maka jika kinerja guru baik akan berdampak pada peningkatan kualitas perserta didik di Sekolah Menengah Kejuruan Negeri Sekota Pekanbaru. Sesuai pendapat Wibowo (2010) menyatakan studi yang pernah dilakukan menunjukkan bahwah budaya organisasi mampu meningkatkan kinerja guru sangat signifikan dibandingkan dengan sebuah sekolah yang budaya organisasi tidak baik. Sedangkan kompensasi yang sesuai kebutuhan guru akan berpengaruh terhadap peningkatan kinerja guru, sebaliknya jika kompensasi tidak memadai akan berdampak pada kinerja guru yang buruk. Kemudian menurut Dedy Kusumah Wijaya \& Anik Herminingsih (2015) dalan artikel menyatakan komensasi berpengaruh signifikan dan positif terhadap kinerja guru baik. Maka Keberhasilan guru dalam melaksanakan tugasnya juga berarti keberhasilan lembaga pendidikan.

Apa bila Suatu sekolah terus memperhatikan guru dari segi kompensasi maka akan berdampak pada kinerja guru yang meningkat. Dalam memberikan kompensasi sekolah betulbetul memperhitung faktor yang mempengaruhi baik dari dalam sekolah maupun luar. Kompensasi yang tinggi maka akan menghasilkan kerja baik dalam melaksanakan tugas sebagai guru. 


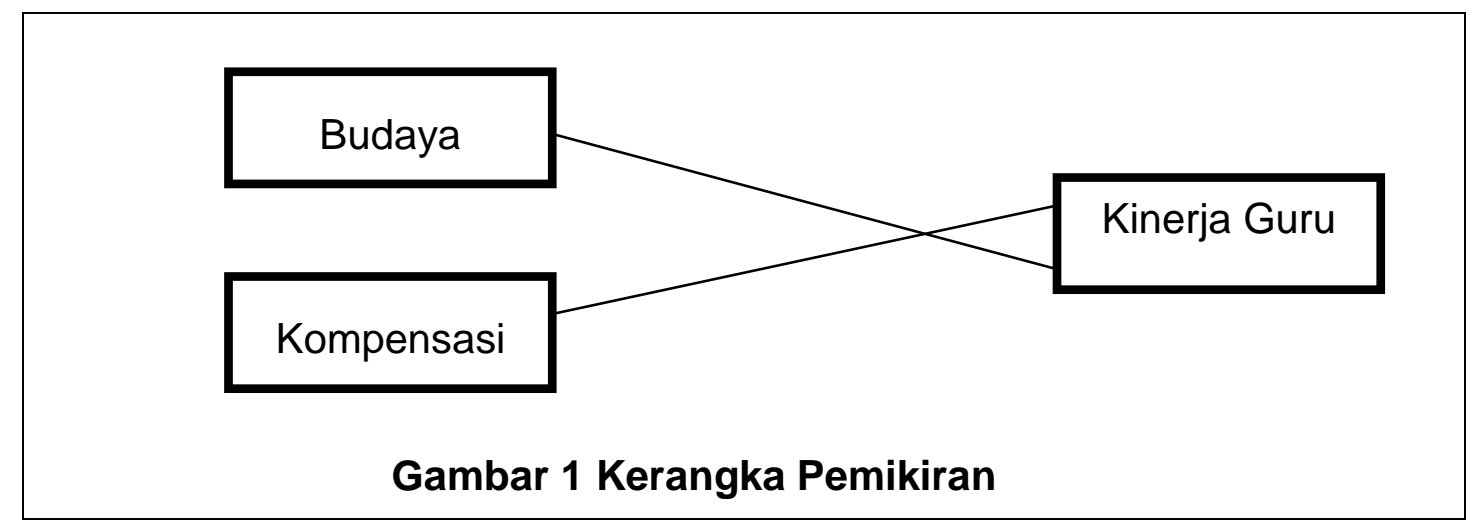

Keterangan :

$\mathrm{X} 1 \quad$ : Budaya Organisasi

$\mathrm{X} 2 \quad$ : Kompensasi

Y : Kinerja Guru

\section{METODOLOGI PENELITIAN}

Penelitian ini dilakukan di Sekolah Menengah Kejuruan Negeri Sekota Pekanbaru. Waktu pelaksanaan pada penelitian hingga pengolahan data diperkirakan selama tiga bulan setelah seminar proposal dilakukan yaitu bulan Oktober-Desember 2017. Teknik penarikan sampel dalam penelitian ini menggunakan sampel secara acak (Random Sampling), Adapun ukuran sampel peneliti menggunakan rumus Slovin dalam buku Akdon (2014: 49), sebagai berikut:

$$
n=\mathrm{N}
$$

$$
\overline{\mathrm{N} \cdot \mathrm{d}^{2}+1}
$$

Dari hasil perhitungan tersebut adalah 79,87 maka dibulatkan menjadi 80 sampel. Berdasarkan penarikan sampel secara acak (random sampling) untuk menentukan jumlah sampel di Sekolah Menengah Kejuruan Negeri Sekota Pekanbaru maka masing-masing sekolah secara proportionate sampling. Dari rumus perbandingan di atas maka dapat dirumuskan jumlah sampel disetiap Sekolah Menengah Kejuruan Negeri Sekota Pekanbaru sebagai berikut:

Tabel 1

\begin{tabular}{|c|c|c|c|c|c|}
\hline NO & NAMA SEKOLA & & POPULASI & PENGHITUNGAN & SAMPEL \\
\hline 1 & $\begin{array}{lc}\text { SMK } & \mathrm{N} \\
\text { PEKANBARU }\end{array}$ & 1 & 58 Orang & $58 / 397 \times 80=11,68$ & 12 \\
\hline 2 & $\begin{array}{lc}\text { SMK } & \mathrm{N} \\
\text { PEKANBARU }\end{array}$ & 2 & 107 Orang & $107 / 397 \times 80=21,56$ & 22 \\
\hline 3 & $\begin{array}{l}\text { SMK } \quad \mathrm{N} \\
\text { PEKANBARU }\end{array}$ & 3 & 59 Orang & $59 / 397 \times 80=11,88$ & 12 \\
\hline 4 & $\begin{array}{lc}\text { SMK } & \mathrm{N} \\
\text { PEKANBARU }\end{array}$ & 4 & 49 Orang & $49 / 397 \times 80=9,87$ & 10 \\
\hline 5 & $\begin{array}{lc}\text { SMK } & \mathrm{N} \\
\text { PEKANBARU }\end{array}$ & 5 & 76 Orang & $76 / 397 \times 80=15,31$ & 15 \\
\hline 6 & $\begin{array}{l}\text { SMK } \quad \mathrm{N} \\
\text { PEKANBARU }\end{array}$ & 6 & 27 Orang & $27 / 397 \times 80=5,44$ & 5 \\
\hline 7 & $\begin{array}{lc}\text { SMK } & \mathrm{N} \\
\text { PEKANBARU }\end{array}$ & 7 & 21 Orang & $21 / 397 \times 80=4,23$ & 4 \\
\hline
\end{tabular}

Populasi dan Sampel Penelitian 
Teknik pengumpulan data dari penelitian ini untuk variabel budaya organisasi menggunakan kuesioner yang telah di uji validasi dan reabilitynya. Sedangkan untuk kompensasi dan kinerja guru digunakan dokumentasi. Teknik analisis data dari penelitian ini menggunakan analisis deskriptif dan kuantitatif, (regresi berganda), dengan bantuan SPSS 20. Adapun secara rinci operasional variabel penelitian ini adalah sebagai berikut:

Tabel 2

Matrik Operasional Variabel Penelitian

\begin{tabular}{|c|c|c|c|}
\hline Variabel & Konsep & Indikator & $\begin{array}{c}\text { Skala } \\
\text { Penguk } \\
\text { ur }\end{array}$ \\
\hline $\begin{array}{l}\text { Kinerja } \\
\text { Guru }\end{array}$ & $\begin{array}{l}\text { Kinerja guru adalah suatu } \\
\text { hasil kerja baik secara } \\
\text { kualitas dan kuantitas dalam } \\
\text { menjalankan tugas dan } \\
\text { kewajiban sesuai standar } \\
\text { maupun kreteria yang } \\
\text { ditetapkan oleh sekolah. }\end{array}$ & 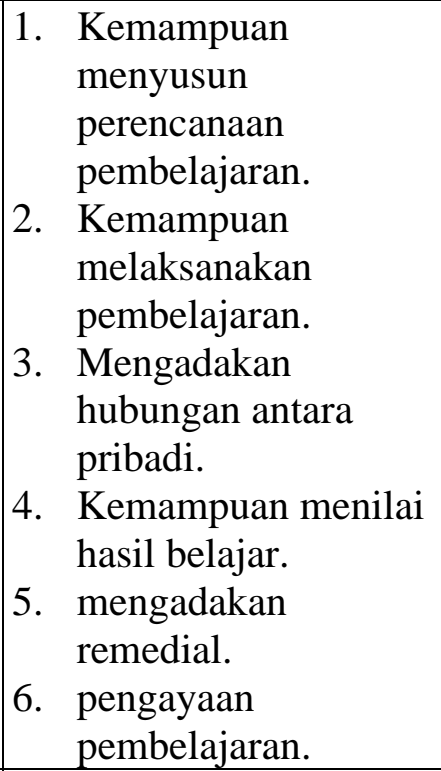 & Rasio \\
\hline $\begin{array}{l}\text { Budaya } \\
\text { Organisasi }\end{array}$ & $\begin{array}{lr}\text { Budaya organisasi } \\
\text { merupakan suatu sistem } \\
\text { makna bersama yang } \\
\text { dipegang oleh anggota, baik } \\
\text { berupa nilai, norma-norma, } \\
\text { dan kebiasaan yang } \\
\text { digunakan untuk } \\
\text { memecahkan masalah, dan } \\
\text { membedakan dengan } \\
\text { organisasi lain. }\end{array}$ & $\begin{array}{l}\text { 1. Inovasi dan } \\
\text { pengambilan resiko. } \\
\text { 2. Perhatian pada hal } \\
\text { detail. } \\
\text { 3. Orientasi pada hasil. } \\
\text { 4. Orientasi pada orang. } \\
\text { 5. Orientasi pada tim. } \\
\text { 6. Agresivitas } \\
\text { 7. Stabilitas. }\end{array}$ & Ordinal \\
\hline $\begin{array}{l}\text { Kompensa } \\
\text { si }\end{array}$ & $\begin{array}{l}\text { Kompensasi merupakan } \\
\text { imbalan yang diberikan } \\
\text { kepada guru atas pekerjaan } \\
\text { yang dilakukan, baik } \\
\text { imbalan financial langsung } \\
\text { tidak langsung, dan non } \\
\text { finalsial sesuai ketetapan }\end{array}$ & $\begin{array}{ll}\text { 1. } & \text { Gaji } \\
\text { 2. } & \text { Bonus } \\
\text { 3. } & \text { Insentif } \\
\text { 4. } & \text { Tunjangan Khusus. } \\
\text { 5. } & \text { Kompensasi karier } \\
\text { 6. } & \text { Fasilitas }\end{array}$ & Rasio \\
\hline
\end{tabular}


pemerintah atau sekolah.

\section{HASIL PENELITIAN DAN PEMBAHASAN}

Pengaruh Secara Simultan (bersama-sama) Budaya Organisasi (X1) Dan Kompensasi (X2) Terhadap Kinerja Guru (Y). Hasil penelitian menunjukkan bahwa terdapat pengaruh positif dan signifikan anatara Budaya Organisasi (X1), dan Kompensasi (X2) secara simultan terhadap kinerja Guru (Y). besar nilai pengaruh secara simultan yaitu $\mathrm{R}^{2}=0.757^{2}=0.573=$ $57,3 \%$ terhadap Kinerja Guru (Y), sedangkan $\quad 42,7 \% \quad(100 \%-57,3 \%)$ merupakan pengaruh dan faktor-faktor lainya yang tidak diteli pada penelitian ini seperti iklim sekolah, disiplin, motivasi, kepemimpinan, komitmen organisasi, dan kepuasan kerja.

Persamaan garis linear yang terbentuk antara Budaya Organisasi (X1) dan Kompensasi (X2) secara bersama-sama (simultan) terhadap Kinerja Guru (Y) adalah Y=64.399+ $0,724 X_{1}+0,200 X_{2}$. Hal ini menunjukkan bahwa semakin baik Budaya Organisasi dan Kompensasi maka semakin baik pula Kinerja guru di Sekolah Menegah Kejuruan Negeri Sekota Pekanbaru. Sebaliknya, semakin buruk Budaya Organisasi dan Kompensasi maka semakin buruk Kinerja guru di Sekolah Menegah Kejuruan Negeri Sekota Pekanbaru.

Dari hasil penelitian tersebut, dapat dijelaskan pentingnya Budaya Organisasi dan Kompensasi sebagai variabel yang mempengaruhi Kinerja guru. Guru yang memiliki Kinerja yang baik di sekolah seperti merasa aman, nyaman, merasa dihargai, mendapatkan kompensasi yang memadai, kemudian mempunyai inisiatif tinggi dan diperlakukan sama dalam peningkatan karir oleh atasan, hal ini akan memunculkan peningkatan Kinerja guru dalam sebuah sekolah. Budaya organisasi dan kompensasi berpengaruh posifit dan signifikan baik secara parsial dan simultan terhadap kinerja guru di sekolah. Adanya budaya organisasi yang baik akan berpengaruh terhadap kinerja guru, maka kinerja guru baik akan berdampak pada peningkatan kualitas perserta didik di Sekolah Menengah Kejuruan Negeri Sekota Pekanbaru. Sesuai pendapat Wibowo (2010) menyatakan studi yang pernah dilakukan menunjukkan bahwah budaya organisasi mampu meningkatkan kinerja guru sangat signifikan dibandingkan dengan sebuah sekolah yang budaya organisasi tidak baik.

Sedangkan kompensasi yang sesuai kebutuhan guru akan berpengaruh terhadap peningkatan kinerja guru, sebaliknya jika kompensasi tidak memadai akan berdampak pada kinerja guru yang buruk. Kemudian menurut Dedy Kusumah Wijaya \& Anik Herminingsih (2015) dalan artikel menyatakan kompensasi berpengaruh signifikan dan positif terhadap kinerja guru. Maka Keberhasilan guru dalam melaksanakan tugasnya juga berarti keberhasilan lembaga pendidikan.

Pengaruh Budaya Organisasi (X1) Terhadap Kinerja Guru (Y) Hasil penelitian ini menunjukkan bahwa terdapat pengaruh positif dan signifikan antara Budaya Organisasi terhadap kinerja guru. Hal ini menunjukkan bahwa semakin baik kompensasi maka semakin baik kinerja guru di Sekolah Menengah Kejuruan Negeri Sekota Pekanbaru, sebaliknya, semakin buruk kompensasi semakin buruk kinerja guru di Sekolah Menengah Kejuruan Negeri Sekota Pekanbaru. 
Budaya Organisasi juga dapat mempengaruhi Kinerja Guru di sekolah. Dengan Budaya Organisasi yang dirasakan oleh guru, maka guru akan cenderung melakukan pekerjaan di luar dari pekerjaan formalnya secara sukarela tanpa mengharapkan imbalan. Budaya Organisasi yang di rasakan guru akan menimbulkan perasaan senang dan menumbukan Kinerja guru yang baik, sehingga mutu organisasi pendidikan akan meningkat . Jika Kinerja guru sudah baik, maka efektifitas dan efisiensi organisasi pendidikan di sekolah akan tercapai sehingga meningkatkan mutu pendidikan.

Hasil penelitian senada dengan hasil penelitian yang menemukan bukti bahwa Budaya Organisasi berhubungan signifikan dengan kinerja guru. Kemudian selaras Dedek Kurniawan Gultom (2014) Dengan demikian hasil penelitian ini memberikan penjelasan dimana sekolah yang memiliki Kinerja Guru yang baik akan cenderung memiliki budaya organisasi.

$$
\text { Pengaruh Kompensasi (X2) }
$$

Terhadap Kinerja Guru (Y) Hasil penelitian ini menunjukkan bahwa terdapat pengaruh positif dan signifikan antara Budaya Organisasi terhadap kinerja guru. Hal ini menunjukkan bahwa semakin baik kompensasi maka semakin baik kinerja guru di Sekolah Menegah Kejuruan Sekota Pekanbaru, sebaliknya, semakin buruk kompensasi maka semakin buruk kinerja guru di Sekolah Menegah Kejuruan Sekota Pekanbaru. kemudian didukung pendapat Dedy Kusumah Wijaya \& Anik Herminingsih (2015) dalan artikel menyatakan kompensasi berpengaruh signifikan dan positif terhadap kinerja guru. Maka Keberhasilan guru dalam melaksanakan tugasnya juga berarti keberhasilan lembaga pendidikan.

Hasil penelitian senada dengan hasil penelitian Mishan (2014) yang menemukan bukti bahwa kompensasi berhubungan signifikan dengan kinerja guru. Kemudian selaras Dedek Kurniawan Gultom (2014) Dengan demikian hasil penelitian ini memberikan penjelasan dimana sekolah yang memiliki Kinerja Guru yang baik akan cenderung memiliki budaya organisasi.

\section{SIMPULAN DAN SARAN}

Berdasarkan pengujian hipotesis dan pembahasan hasil penelitian, pada bab ini akan dibicarakan simpulan, implikasi dan saran yang bersifat sintretik dan sistematik, untuk lebih jelasnya akan dikemukakan satu persatu, maka dapat disimpulkan bahwa secara simultan, terdapat pengaruh positif dan signifikan antara variabel Budaya Organisasi (X1) dan Kompensasi (X2) terhadap Kinerja Guru (Y) di Sekolah Menengah Kejuruan Negeri Sekota Pekanbaru. Besar pengaruh tersebut sebesar $\mathrm{R}^{2}=$ $0.757^{2}=0.573=57,3 \%$ terhadap Kinerja Guru (Y), sedangkan 42,7\% (100\%-57,3\%), sisannya merupakan pengaruh faktor-faktor lain yang tidak diteliti dalam penelitian.

Berdasarkan pengaruh variabel budaya organisasi terhadap kinerja guru adalah sebesar $0,225^{2}=0,050625=$ $5,00 \%$ kontribusi variabel $5,00 \%$ sedangkan sisanya di tentukan oleh variabel lain. Informasi ini memberikan keterangan bahwa variabel budaya organisasi memberikan pengaruh terhadap kinerja guru. Hasil penelitian ini menginformasikan bahwa budaya organisasi di miliki sekolah dapat meningkatkan kinerja guru yang optimal sehingga diharapkan akan mempengaruhi hasil kerja maupun kualitas pelayanan bagi siswa di sekolah.

Besarnya pengaruh variabel kompensasi terhadap kinerja guru 
adalah sebesar $0,730^{2}=0,5329=5,32 \%$. Kemudian sisanya ditentukan oleh variabel lain. Informasi ini memberikan keterangan bahwa variabel kompensasi memberikan pengaruh terhadap kinerja guru. Temuan penelitian ini menerangkan bahwa pemberian kompensasi yang optimal akan meningkatkan hasil kerja dan kualitas pelayanan bagi siswa di sekolah.

Berdasarkan hasil penelitian dan kesimpulan seperti yang dipaparkan sebelumnya, maka pada bagian ini perlu diberikan saran kepada pihak-pihak yang terkait dalam penelitian ini : 1). Bagi kepala sekolah dan Guru di Sekolah Menengah Kejuruan Negeri Sekota Pekanbaru. Penelitian ini dapat memberikan sumbangan pemikiran bagi pengembangan ilmu administrasi pendidikan, khususnya berkenaan dengan kinerja guru. Mengingat Budaya Organisasi besar pengaruhnya terhadap peningkatan kinerja guru, untuk itu setiap pemerintah provinsi dan kepala sekolah bisa memberikan kompensasi yang memadai karena bisa meningkatkan kinerja guru. 2). Bagi penulis, hasil penelitian ini dapat menambah wawasan, pengetahuan dalam melakukan analisis mengenai Budaya Organisasi dan kompensasi terhadap kinerja guru. 3). Bagi peneliti selanjutnya, penelitian ini dapat dijadikan salah satu referensi dalam melakukan kajian terhadap masalah yang sama dan menambah wawasan pengetahuan bagi yang memanfaatkannya. Untuk kesempurnaan dan kelanjutan penelitian ini, peneliti selanjutnya dapat dilakukan dengan lebih memperdalam materi dari masing-masing variabel seperti hubungan sosial diantara guru dan kepala sekolah, situasi kerja untuk meningkatkan mental, komunikasi antar pribadi, konflik, promosi, jabatan, peningkatan kesejahteraan guru, pembagian tugas, dan pola kepemimpinan.

\section{DAFTAR PUSTAKA}

Barnawi \& Arifin, Mohammad. (2012). Kinerja Guru Profesional. Jogjakarta : Ar-Ruzzz Media.

Colquitt, Jason A. Dkk. (2004). Organisational Behavior: Improving Performance and Commitment In The Workplace. New York : McGraw-HillIrwin.

Fahmi, Irham. (2011), Manajemen Kinerja. Bandung : Alfabeta.

Fatimah, dkk. (2015). Komunikasi Kepala Sekolah dalam Meningkatkan Kinerja Guru Pada SMA N 1 Geumpang Kabupaten Pidie. Jurnal Administrasi Pendidikan. Vol. 3. No. 4.

Gultom, Dedek Kurniawan. (2014). Pengaruh Budaya Organisasi Perusahaan dan Motivasi Terhadap Kinerja Karyawan Pada PT. Perusahaan Gas Negara (PERSERO) Tbk Medan. Vol. 14. No. 02.

Hakim, Abdul \& Hadipapo, Anwar. (2015). Peran Kepemimpinan Dan Budaya Oragaisasi terhadap Kinerja SMD Di Wawatobi. Ekobis, Vol. 16, N0. 1.

Hameed, Abdul,. (2014). Impact of Compensation on Employee Performance (Empirical Evidence from Banking Sector of Pakistan). Vol. 5 No. 2.

Hardiyana, Aan \& dkk. (2013). Pengaruh Budaya Organisasi dan Kompensasi Terhadap Motivasi 
kerja Serta Implikasinya Terhadap Kinerja Guru. Jurnal Ekonomi, Bisnis \& Entrepreneurship. Vol. 7, No.2.

Kadarisman, Muhammad. (2012). Manajemen Kompensasi, Jakarta: PT. Rajagrafindo Persada.

Koesmono,Teman (2005) Pengaruh Budaya Organisasi Terhadap Motivasi Dan Kepuasan Kerja Serta Kinerja Karyawan Pada Sub Sektor Industri Pengolahan Kayu Skala Menengah Di Jawa Timur, Jurnal Ekonomi Manajemen. VOL. 7, NO. 2.

McShane \& Glinow, Von (2008). Organizational Behavior. New York: McGraw-Hill Irwan.

Mishan. (2014). Pengaruh Motivasi Kerja Guru Dan Budaya Organisasi Terhadap Kinerja Guru SMA Negeri Di Kota Sibolga. Jurnal Bisnis dan Manajemen Eksekutif. Vol. 1, No. 2.

O, Owoyemi O, \& O, Ekwoaba J. (2014). Organisational Culture: A Tool for Management to Control, Motivate and Enhance Employees' Performance Vol. 3. No. 3.

Peraturan Menteri Pendidikan Nasional Nomor 35 Tahun 2010 Tentang Petunjuk Teknis Pelaksanaan Jabatan Fungsional Guru dan Angka Kreditnya.

Peraturan Pemerintah Republik Indonesia Nomor 19 Tahun 2005 Tentang Standar Nasional Pendidikan.
Priyono \& Marnis. (2008). Manajemen Sumber Daya Manusia. Sidoarjo Zifatama Publisher.

Putra, Endang Tritana \& Yunita, Yelvia (2014). Pengaruh Kepemimpinan Kepala Sekolah dan Budaya Organisasi Terhadap Kinerja Guru SMA N 1 Simpang Empat. Jurnal Apresiasi Ekonomi. Vol. 2, No. 3.

Riduwan. (2010). Metode dan Teknik Menyusun Tesis. Bandung : Alfabeta.

Riduwan \& Kuncoro, Engkos Achmad. (2015). Cara Menggunakan dan Memakai Path Analysis. Bandung : Alfabeta

Rivai, Veithal. (2004). Manajemen Sumber Daya Manusia untuk Perusahaan. Jakarta: RajaGrafindo Persada.

Safrudin Muhyi , Encep. (2011). Kepemimpinan Pendidikan Tranfornasional Jakarta : Diadit Media Pers.

Sanusi, Achmad \& Sutikno, Sobry M. (2009). Kepemimpinan Sekarang \& Masa Depan. Bandung : Prospect.

Shahad, Fakhar, dkk. (2012). Impact of Organizational Culture on Organizational Performance : $A n$ Overview. Vol. 3, No. 9

Supardi. (2014). Kinerja Guru.Jakarta : Rajawali Pers.

Sutarto. (2006). Dasar-Dasar Organisasi. Yogyakarta: Gadjah Mada University Press. 
Sutrisno, Edy. (2011). Budaya Organisas. Jakarta : Prenada Media Group.

Taurisa, Chaterina Melina, \& Ratnawati, Intan. (2012). Analisis Pengaruh Budaya Organisasi dan Kepuasan Kerja Terhadap Komitmen Organisasional Dalam Meningkatkan Kinerja Karyawan (Studi pada PT. Sido Muncul Kaligawe Semarang). Vol. 19. No. 02.

Torang, Syamsir. (2014). Organisasi dan Manajemen. Bandung: Alfabeta.

Ulfatin, Nurul dan Triwiyanto, Teguh. (2016). Manajemen Sumber Daya Manusia Pendidikan. Jakarta: Rajawali Pers.

Undang-Undang Dasar Negara Kesatuan Republik Indonesia Tahun 1945

Undang-Undang Republik Indonesia No. 14 Tahun 2005 Tentang Guru dan Dosen.

No. 16 Tahun 2007 Tentang Standar Kualifikasi Akademik dan kompetensi Guru.
No. 18 Tahun 2007 Tentang Sertifikasi Bagi Guru Dalam Jabatan.

No. 20 Tahun 2003 Tentang Sistem Pendidikan Nasional

Nomor 19 Tahun 2005 tentang Standar Nasional Pendidikan.

Wibowo. (2016). Budaya Organisasi. Jakarta: PT. RajaGrafindo Persada.

Wijaya, Dedy Kusumah. (2015). Pentingnya Komuniksi Organisasi, Motivasi Kerja dan Kompensasi untuk Meningkatkan Kinerja Guru. Jeam. Vol 14.

Wijaya, Tanto dan Andreani, Fransisca. (2015). Pengaruh Motivasi dan Kompensasi Terhadap Kinerja Karyawan Pada PT Sinar Jaya Abadi Bersama. Agora Vol. 3, No. 2.

Zakharia, Febry. (2014). Pengaruh Budaya Organisasi Dan Kepuasan Kerja Terhadap Kinerja Guru SMP Yadika 3 Tangerang. Jurnal Ilmu Ekonomi Dan Sosial, Jilid 3, Nomor 01. 